\section{B A Institute of \\ YK Business Administration \\ 六下 \\ Karachi \\ Leadership and Ideas for Tomorrow}

Business Review

Volume 7 Issue 2 July-December 2012

7-1-2012

\title{
Gender differences in trait emotional intelligence: A comparative study
}

Salman Shahzad

Institute of Clinical Psychology, University of Karachi, Pakistan

Nasreen Bagum

Area Study Center for Europe,University of Karachi, Pakistan

Follow this and additional works at: https://ir.iba.edu.pk/businessreview

Part of the Cognitive Psychology Commons, and the Gender and Sexuality Commons

(c) (i)

This work is licensed under a Creative Commons Attribution 4.0 International License.

\section{Recommended Citation}

Shahzad, S., \& Bagum, N. (2012). Gender differences in trait emotional intelligence: A comparative study. Business Review, 7(2), 106-112. Retrieved from https://doi.org/10.54784/1990-6587.1207

This article is brought to you by iRepository for open access under the Creative Commons Attribution 4.0 License and is available at https://ir.iba.edu.pk/businessreview/vol7/iss2/8. For more information, please contact irepository@iba.edu.pk. 


\title{
DISCUSSION
}

\section{Gender Differences in Trait Emotional Intelligence: A Comparative Study}

\author{
Salman Shahzad \\ Institute of Clinical Psychology, University of Karachi, Pakistan \\ Nasreen Bagum \\ Area Study Center for Europe,University of Karachi, Pakistan
}

\begin{abstract}
The objective of present study is to determine the difference between male and female on the variable of trait emotional intelligence. After the detailed literature review the following hypothesis was formulated; There would be a difference between males and females on the variable of trait emotional intelligence. The sample consisted of 100 university students. The entire sample divided into two groups. The sample consisted of 100 university students, recruited from University of Karachi, including 51(51\%) males and 49 (49\%) females. The age range of both groups were from 18 to 30 years (Mean age $=23.78$ years) with males (Mean Age $=24.18$ years) and female (Mean Age = 23.37 years) and minimum educational level was intermediate $\left(12^{\text {th }}\right.$ class) and highest education was Maters $\left(16^{\text {th }}\right.$ Class). The measures used in the research included, Personal Information Form and Trait Emotional Intelligence Questionnaire by (Petrides \& Furnham, 2003) that was administered to measure the trait emotional intelligence. ' $t$ ' test for independent sample was calculated to determine the difference of trait emotional intelligence between males and females in statistical terminology. The results showed a significant difference between males and females on the variable of trait emotional intelligence $t(98)=2.773, p<0.01$. The analysis showed that the male participants demonstrated higher level of emotional intelligence as compared to females.
\end{abstract}

Keywords: Gender, Trait Emotional Intelligence, Student

\section{Introduction}

Emotional intelligence is a main topic of many discussions among researchers, academicians and scholars. It has received attention as an important aspect which is valuable in understanding and predicting individual's behavior at home, at school and at work place. The term "Emotional Intelligence” was first given by Salovey and Mayer in the early 1990's. It gained its popularity among professionals as well as among general public when Daniel Goleman in 1995, published his book titled "Why it can matter more than IQ”. Further Mayer, Salovey, \& Caruso (2000) and Afolabi (2004) argued that emotional intelligence is not a single trait but it is a composite of distinct emotion 
reasoning abilities. Perceiving emotions consist of understanding and interpreting the meaning of diverse emotional conditions, as well as their associations with other sensory experiences. Understanding one's emotions involve recognition of how basic emotions are bring together to form complex emotions within an individual, and the regulation of emotions include the control of one's as well as others emotions too.

There are many definitions of emotional intelligence that have been put forward, but the basic concept is same that the emotionally intelligent individuals have better understanding of their own and others emotions. There are numerous conceptualizations of emotional intelligence in the literature (e.g., Bar-On, 1997; Goleman, 1995; Mayer \& Salovey, 1997; Petrides \& Furnham, 2001). According to Bar-On (1997) EQ as "an array of non-cognitive skills that influence one's ability to succeed in coping with environmental demands and pressures”. Bar-On divided EQ into five domains which includes; intra-personal, inter-personal, adaptability, stress management and general mood (as cited in Reiff, 2001). According to Goleman (1995) emotional intelligence means “emotional literacy”. Individual with emotional intelligence have ability to relate with others have the ability to empathize, have well developed social skills and have ability to use their emotional understanding to direct their behaviors. According to Salovey and Mayer (1997) emotional intelligence is "the ability of individual to understand his or her emotions as well as others emotions and feelings, to distinguish between them and to use this knowledge in his decision making process and actions”. According to Petrides and Furnham (2006) there is a conceptual distinction of emotional intelligence such as "trait EI (emotional self-efficacy), which concern emotion related traits and self-perceived abilities which is measured through self report questionnaires, and second is the ability EI (cognitive-emotional ability), which concerns with the abilities related to emotion and is measured through maximum-performance tests.

The current research is based on the trait emotional intelligence (emotional self efficacy) which focuses on the gender difference in trait EI. According to Petrides and Furnham (2006) “Trait EI is a constellation of emotion-related self-perceptions and dispositions” (e.g., emotion perception, emotion management, empathy and impulsivity) assessed through self-report questionnaires. Many empirical studies have been done to understand the systematic differences in a way in which the two genders experience the workplace and its demands (Roxburgh, 1996).

Research on individual differences has shown much attention on the impact of emotional abilities as personal resources of individuals. Among the emotional abilities the emotional intelligence (EI), is one of the important psychological construct, is partly responsible for bringing a new sphere of studies to explain individual differences in human behavior. Recently, studies have been done which has contributed to this interest by shedding light on the advantages of being an emotionally intelligent individual in areas as diverse as; physical health (Woolery \& Salovey, 2004), mental health (Tsaousis \& Nikolaou, 2005).

In their research Mandell and Pherwani (2003) examined relationships between emotional intelligence, gender and leadership. They found significant, predictive relationships between these variables. Researchers have sought the differences in EI across gender. For example, Bar-On (1997) and Goleman (1995) found a differential EI profile of males and females. In their researches, researchers (Mayer et al., 1999; Mayer \& Geher, 1996; Mandell \& Pherwani, 2003) found that women scored higher on the variable of emotional intelligence than men. On the other hand, Petrides and Furnham (2000) 
found that men score higher on the variable of emotional intelligence as compared to women. Goleman (1998) conducted a research to determine the gender difference on the variable of emotional intelligence and found no difference between men and women.

Previously, studies conducted to assess the gender differences on the variable of emotional intelligence have found controversial findings. Studies in which self report measures were used to assess gender differences on the variable of EI do not generally find significant differences (Fernández-Berrocal, Extremera, \& Ramos, 2004) or, in other cases, males scored slightly higher on intrapersonal sub domain than women (Bar-On, Brown, Kirkcaldy, \& Thomé; 2000; Petrides \& Furhman, 2000).

A research Goleman (1998) and argued that that "men and women seem equally able to increase their emotional intelligence". Study conducted by Stein (as cited in Murray, 1998), in which both men and women were assessed on the variable of emotional intelligence. Stein found that on the sub scales of empathy and social responsibility women scored higher than men, while men scored higher on the subscales of stress tolerance and self-confidence than women. He concluded that both women and men are equally intelligent emotionally, but they are strong in different domains.

Previous researches have given contradictory results regarding the emotional intelligence in males and females. There are few research studies that have been done on the emotional intelligence in general and specifically on gender differences. Keeping in mind the current study was designed to determine the possibility of gender differences on the variable of emotional intelligence in our own cultural framework by formulating a hypothesis that, "there would be differences between male and female students on the variable of trait emotional intelligence”.

\section{METHOD}

\section{Participants}

In this study, the sample of university students were recruited from university of Karachi (a city of Pakistan). Sample of the present research comprised of 100 (Mean Age $=23.78$ years, SD = 3.211) participants. The entire sample was divided into two groups, i.e., 51 males (Mean age $=24.18$ years, $\mathrm{SD}=3.211$ ) and 49 females (Mean age $=23.37$ years, $\mathrm{SD}=3.426)$. Their minimum education was intermediate $\left(12^{\text {th }}\right.$ grade $)$ and maximum education was Master $\left(16^{\text {th }}\right.$ Grade). The sample belonged to middle and upper socioeconomic status.

\section{Procedure}

A list of departments of university of Karachi was randomly selected for data collection. A letter of consent describing the research project and inviting participants was provided to heads/authorities of the departments, along with the sample of questionnaires containing items regarding Personal Information Form and trait emotional intelligence scale. The participants were also introduced to the researcher, informed of what participation would entail, and given a consent form sheet that explained the objective of the study. Initially students of their respective classes were approached, and Personal Information Form was filled by the examiner. After that Trait emotional Intelligence Scale (TEIQue; Petrides \& Furnham, 2003) was administered to assess the emotional intelligence between the groups. After the administration of scales all the participants were thanked by the examiner for their time and voluntarily participation. 


\section{Statistical Analysis}

Statistical methods used for analysis of data in the present research were descriptive statistics and ' $t$ ' test. ' $t$ ' test for independent sample was computed to determine the difference between males and females on the variable of trait emotional intelligence.

\section{Description of Measures}

\section{a) Demographic Information:}

Personal information would be obtained through items which focus on the participant's age, gender, highest level of education, class in which he/she is studying, grade / division obtained in last class, family structure, and monthly family income.

\section{b) Trait emotional intelligence questionnaire (TEQI- SF): (Petrides \& Furnham, 2003).}

This is a 30-item questionnaire designed to measure global trait emotional intelligence (trait EI). It is based on the full form of the TEIQue (Petrides \& Furnham, 2003), which covers the trait EI sampling domain comprehensively. The TEIQue-SF provides highly reliable global trait EI scores that correlate meaningfully with a wide range of diverse criteria, including coping styles, life satisfaction, personality disorders, perceived job control, and job satisfaction (Petrides et al., 2003). Items are responded to on a 7-point Likert scale.

\section{RESULTS}

Table 1

Descriptive statistics for the age of the entire sample

\begin{tabular}{lccccc}
\hline Variable & Group & Minimum & Maximum & $\boldsymbol{M}$ & SD \\
\hline \multirow{2}{*}{ Age } & Male & 18.00 & 30.00 & 24.18 & 3.211 \\
& Female & 18.00 & 30.00 & 23.37 & 3.426 \\
\hline
\end{tabular}

Table 2

Independent Samples 't' Test for participants' Trait Emotional Intelligence

\begin{tabular}{clcccccccc}
\hline Variable & Group & $\boldsymbol{N}$ & $\boldsymbol{M}$ & $\boldsymbol{S D}$ & $\boldsymbol{S E M}$ & $\boldsymbol{d f}$ & $\boldsymbol{t}$ & $\begin{array}{c}\text { Sig. } \\
\text { (2- } \\
\text { tailed) }\end{array}$ & $\begin{array}{c}\text { Std. Error } \\
\text { Difference }\end{array}$ \\
\hline $\begin{array}{c}\text { Trait } \\
\begin{array}{c}\text { Emotional } \\
\text { Intelligence }\end{array}\end{array}$ & Male & 51 & 147.51 & 22.253 & 3.116 & & & & \\
& Female & 49 & 135.33 & 21.650 & 3.093 & & & & \\
\hline
\end{tabular}




\section{Discussion}

Results in Table 2 shows that there is a difference between mean scores of male and female with respect to emotional intelligence, with males having higher level of trait emotional intelligence than that of females. However, the difference touched 0.01 level. The results obtained from present study are consistent with the findings of studies conducted by Chu (2002) who revealed that males have higher level of emotional intelligence than that of females. However, these findings contradicted the results of previous studies (e.g., Mayer, Salovey, \& Caruso, 2002; Palmer, Gignac, Manocha, \& Stough, 2005; Singh, 2002). They all found females to have higher emotional intelligence than that of males.

A possible explanation might be that men perceive themselves more emotionally intelligent, as has been observed for other self-reported characteristic. Another reason for the present findings might be due to the fact that emotional intelligence deals with managing and expressing individual's emotions as well as social skills. Since, males tend to control their emotion well and are able to develop healthy relationships as compared to females, so they are emotional intelligence than that of females. This is perhaps because of the society, which socializes the two genders differently as has been found in studies by Duckelt and Raffalli (1989) and Sandhu and Mehrotra (1999). Singh (2007) reported that women are not necessarily 'smarter' than men on the variable of emotional intelligence, nor are men are 'superior' to women on this variable. But both of them as individual as well as groups share personal profile of strengths and weaknesses in each domain. For example, if some one empathic to others may lack certain abilities to cope up with distress; some may have deep understanding of other's emotions, but may be socially incompetent. Both men and women have equal contribution to society, but women have to face discrimination in certain areas due to her role as female. This discrimination may possibly effects on the emotional development of females.

This study with its capacity would help to better understand the meaning of gender differences in the field of emotional intelligence and suggest proper interventions for raising emotional both men and women. So this area needs more exploration. Findings of this research study will prove beneficial for educators, parents, counsellors for providing better knowledge about this vital component of success and its important predictors. An understanding of all these aspects will provide a better insight into the success equation required in life. Thus, the above finding may not be conclusive and can't generalize to all men and women but suggestive of the trend.

Emotional intelligence plays an important part in every aspect of people's lives for example, in their research Siddiqui, Shahzad and Ansari (2009) found that there is a significant positive relationship of trait emotional intelligence with happiness and life satisfaction. With all that in mind, EQ training with well planned manner to both males and females graduate students is necessary and would be an advantage in their lives. This may help them to develop stable and trusting relationships, to understand themselves as well as others in a better way, to control their feelings effectively, to interpret others behavior objectively and treat other people with empathy.

Human emotions are essential aspect of personality. It would be interesting and valuable to examine the other domains of personality in future research that may possibly have a relationship with emotional intelligence of both group. As mentioned earlier that trait emotional intelligence is a constellation of trait to have global trait EI. So the study of 
multiple facets of trait emotional intelligence may give a deep understanding about the individual\s global trait emotional intelligence.

\section{Acknowledgement}

We are thankful to K. V. Petrides and Adrian Furnham, the authors of trait emotional intelligence questionnaire for giving us permission to use the questionnaire in our research studies as well as to translate and adapt this questionnaire into Urdu. We are also thankful to the participants of our study for sparing their precious time to participate in the study. 送

\section{References}

Afolabi, A. O. (2004). Influence of five-factor personality attributes, need for achievement and emotional intelligence on work team interaction processes in the Niger-Delta. An Unpublished Ph.D Thesis, University of Ibadan, Nigeria.

BarOn, R. (1997). BarOn Emotional Quotient Inventory. Toronto: Multi-Health Systems.

Bar-On, R., Brown, J. M., Kirkcaldy, B. D., \& Thomé; E. P., (2000). Emotional expression and implication for occupational stress; an implication for the Emotional Quotient Inventory (EQ-i). Personality and Individual Differences, 28, 1107-1118.

Chu, J. (2002). Boys’ development. Reader's Digest, 94-95.

Duckelt, E. \& Raffalli, M (1989). Taking care, maintaining the self and the home in adolescents. Journal of Youth and Adolescence, 18(6), 549.

Fernández-Berrocal, P. Extremera, N., \& Ramos, N. (2004). Validity and reliability of Spanish modified version of the Trait Meta Mood Scale. Psychological Reports, 94, 751755.

Goleman, D. (1995). Emotional Intelligence. New York: Bantam Books.

Goleman, D. (1998). Working with emotional intelligence. New York: Bantam Books

Mandell, B. \& Pherwani, S. (2003). Relationship between emotional intelligence and transformational leadership style: a gender comparison. Journal of Business and Psychology, 17, 387- 404.

Mandell, B., \& Pherwani, S. (2003). Relationship between emotional intelligence and transformational leadership style: A gender comparison. Journal of Business Psychology, 17(3), 387-404.

Mayer, J. D. \& Geher, G. (1996). Emotional Intelligence and its identification of emotion. Intelligence, 22, 89-113.

Mayer, J. D., Salovey, P., \& Caruso, D. (1999). Instruction manual for the MSCEIT: Mayer-Salovey-Caruso Emotional Intelligence Test. Toronto, Ontario, Canada: MultiHealth Systems.

Mayer, J. D., Salovey, P., \& Caruso, D. (2000). Models of Emotional Intelligence. In: R. Sternberg (Ed.), Handbook of Intelligence. Cambridge, UK: Cambridge University. 
Retrieved from: http:// www.unh.edu/ emotional_intelligence/EI\%20Assets/Reprints... EI\%20Proper/EI2000ModelsSternberg.pdf.

Mayer, J. D., Salovey, P., \& Caruso, D. R. (2002). Mayer-Salovey-Caruso Emotional Intelligence Test (MSCEIT) item booklet, Version 2.0. Toronto, Ontario, Canada: MHS Publishers.

Murray, B. (1998). Does “emotional intelligence” matter in the workplace? APA Monitor, 29(7). Retrieved October 26, 2005 from http://www.apa.org/ monitor/jul98/ emot.html.

Palmer, B. R., Gignac, G., Manocha, R., \& Stough, C. (2005). A psychometric evaluation of the Mayer-Salovey-Caruso Emotional Intelligence Test Version 2.0. Intelligence, 33, 285-305.

Petrides, K. V. \& Furnham, A. (2003). Trait emotional intelligence: Behavioural validation in two studies of emotion recognition and reactivity to mood induction. European Journal of Personality, 17, 39-57.

Petrides, K. V., \& Furhman, A. (2000). Gender differences in measured and self estimated trait emotional intelligence, Sex Roles, 42, 449-461.

Petrides, K. V., \& Furnham, A. (2001). Trait emotional intelligence: Psychometric investigation with reference to established trait taxonomies. European Journal of Personality, 15, 425-448.

Petrides, K. V., \& Furnham, A. (2006). The role of trait emotional intelligence in a gender-specific model of organizational variables. Journal of Applied Social Psychology, 36, 552-56

Reiff, H. B. (2001). The relation of L D and gender with emotional intelligence in college students. Journal of Learning Disabilities, 34 (1), 66-79.

Roxburgh, S. (1996). Gender differences in work and wellbeing: Effects of exposure and vulnerability. Journal of Health and Social Behavior, 37, 265-277.

Salovey, P. \& Sluyter, D. (1997). Emotional Development and Emotional Intelligence: Educational Implications. New York. Basic Books.

Sandhu, P. \& Mehrotra, N (1999). Time pattern of female students with special reference to leisure time activities. Indian Journal of Social Research, 40(4), 285-296.

Riaz, Z, Shahzad, S., \& Ansari, K. (2009). Trait emotional intelligence as a determinant of life satisfaction and subjective happiness. Pakistan Journal of Psychology, 40 (1), 93-101

Singh, D. (2006). Emotional Intelligence at Work: A Professional Guide. New Delhi, India: Sage Publications Inc.

Tsaousis, I., \& Nikolaou, I. (2005). Exploring the relationship of emotional intelligence with physical and psychological health functioning. Stress and Health, 21, 77-86.

Woolery, A., \& Salovey, P. (2004). Emotional intelligence and physical health. In I. Nyklǐcek, L. Temoshok, \& A. Vingerhoets (Eds.), Emotional expression and health. Advances in theory, assessment and clinical applications (pp. 154-168). Hove and New York: Brunner- Routledge. 